\title{
COMPARATIVE ANALYSIS OF FINANCING MODELS OF HIGHER EDUCATION
}

\author{
Birutė Pranevičienė
}

\author{
Aurelija Pūraitè
}

\author{
Violeta Vasiliauskienè \\ Žaneta Simanavičienè \\ Mykolas Romeris University, Lithuania
}

\begin{abstract}
The paper aims to present a comparative analysis of financing models of higher education in Europe. Higher education institutions can function properly and ensure the quality of research and studies when there is sufficient funding. Higher education institutions in Europe face a demanding financial situation in which traditional models of funding have been transformed and continue to change gradually. The paper consists of two parts. In the first part the trends in financing higher education in Europe are presented and evaluated. An analysis of the legal regulation and deficiencies of this field are presented. The second part of the paper is devoted to the description of state financing methods of higher education. The main methods of the distribution of the state financing among the institutions of higher education are discussed and the advantages and disadvantages of those methods are evaluated, as well as the experience of other countries in financing higher education. The problematic aspects of the state regulation of financing higher education are analysed by using the methods of document analysis, critical-analytical methods, analysis of scientific literature, historic analysis, systematic analysis, method of the source-content analysis, comparative method.
\end{abstract}

Keywords: financing methods of higher education, financing of higher education, higher education.

\section{Introduction}

The financing system of higher education institutions is one of the most important elements which determine the whole system of higher education both institutional, qualitative, accessibility, and other dimensions. The need for higher education in the last few decades has increased more than the state abilities to ensure proper public funding for the system of higher education (Salmi, Hauptman, 2006). The main financing source of higher education in Europe currently is the state: in the EU the government's share of total spending on education in 2012 ranged from $69 \%$ in Portugal up to close to $100 \%$ in Sweden, Finland and Luxembourg (Eurostat, 2016). Direct budget assignations in the EU 
countries for tertiary institutions comprise from $60 \%$ to $90 \%$ of their received resource income. Only in Great Britain the private funding to higher education reaches $25 \%$ of the whole financing amount, in other states this indicator does not exceed 20\% (Canning et al., 2007). Since the state still remains the main funder of the system of higher education, the applied method of state financing must guarantee effectiveness, quality and must be sufficient. Whatever the financial strength of a state is, whatever external financial sources the institutions of higher education could invoke, and it is obvious that financial aspects are the most vulnerable and relevant to the activities of tertiary education institutions. Therefore, a few fundamental strategic questions arise to the states and higher education institutions: how to allocate the restricted financial resources of the state budget, designated to higher education; what legal and financial mechanisms are optimal for achieving ultimate accessibility of higher education, quality of studies and competitive abilities of the national higher education institutions in the conditions of globalization. The scholars offer different models of financing the higher education system, incorporating various financial sources and methods, theoretic concepts and reasoning, revealing the advantages and weaknesses of such models and stressing the relation of state and private funding and its importance. According to the scientists, two types of financing higher education may be determined: according to the interaction of financing sources and the impact of funding subjects on the system of higher education-bureaucratic, collegial and market financial models; according the addressee of state fundingthe institutional, programme financing, and the method of financing the service receiver (Pranevičienè, Pūraite, 2010). However, at the present moment, the state does not have a clear strategic vision of higher education, and the means of regulation chosen by the state, and the tactics and scope of their selection are not coordinated and do not add to the dispersion of goals and the mission of higher education.

The aim of the paper: to present a comparative analysis of financing models of higher education in Europe.

In order to achieve above-mentioned aim, the following tasks were set:

- $\quad$ to discuss the main methods of the distribution of state financing among the institutions of higher education; to evaluate the advantages and disadvantages of those methods and to evaluate the experience of other countries in financing higher education;

- to evaluate trends in financing higher education in the EU and to determine shortages of the legal regulation of this field.

The problematic aspects of the state regulation of financing higher education are analysed by using the methods of document analysis, critical-analytical methods, analysis of scientific literature, historic analysis, systematic analysis, the method of source content analysis, the comparative method. 


\section{Trends in financing higher education in Europe}

It is evident that it is not possible to ensure the quality and effectiveness of the system of higher education only by the funds provided by the state. Therefore under all the models of financing higher education (except for the strictly centralized financing of higher education), the institutions of higher education are able to earn money or to attract private funds, the source of which can be various the student tuition for studies, competition based - programme based financing of scientific research, as well as the income obtained on the basis of contracts, concluded with commercial partners. The trend may be noticed, as the share of GDP allocated to the higher education field is decreasing. For example, the states which allocate the most funds to higher education are Denmark (in 2002 the share of GDP was 2.8 percent, in $2012-2.3$ percent), Sweden (in 2002 the share allocated was 2.3 percent, in 2012 it was 2 percent), and Finland (both in 2002 and 2012 the size remained the same, 2.2 percent). The average share of GDP allocated to tertiary education in the EU was 1.3 percent in 2012 (Eurostat, 2012). It is interesting to note, that in the USA this share allocated to higher education was stable and both in the year 2002 as well as in the year 2012 comprised 2.8 percent of GDP. In order to reach the level of investment to the system of higher education of the USA, the European Union should invest approximately additional 140 milliard Euros a year, by attracting the sources from the private sector (CEGES, 2007). Spending as a percentage of GDP by the United States ( 2.8 percent) was higher than the OECD average (1.5 percent) and higher than that of any other OECD country reporting data (National Centre for Education Statistics, 2012). However, the prognosis is that until the year 2020 the higher education spending is going to decline to 1.7 percent of GDP because of the financial crisis. In the EU, tertiary education accounted for one-fifth to one-third of total educational expenditure in all of the EU Member States.

There is a tendency in many EU countries (except for the United Kingdom and Ireland) that government appropriations are still the dominant source of revenues. Their share exceeds two-thirds in all countries, except for the UK. Tuition fees are an important source of revenues in only three countries, i.e. Italy, Spain and the UK, while in the other countries fees account for a relatively small share of revenues. The aggregate share of grants and contracts most of the countries considered show a range of between 10 and 20 percent. Funding is one of the key intervention instruments - for the government (ministries, funding councils) as well as university decision-makers (Executive Boards, deans, department heads). In higher education, regulation is related to topics such as standards for the quality of degrees (accreditation), the number of students admitted to public institutions and the freedom of higher education institutions to 
charge tuition fees and engage in various kinds of other income generating activities (Funding Higher Education, 2010).

Most discussions regarding financing the state and the private higher education system are raised regarding the question of the tuition fee. There are states in Europe where studies are fully or in part for free (except for the registration fee and fees for additional services provided by the university). Such examples are Austria, Denmark, Finland, Norway, Sweden, Germany. The states where all students or a portion of the students pay for their studies themselves usually have state support mechanisms for the students (loans, compensation for interest on loans, tax privileges, scholarships for certain social groups etc.). But lately we could notice a tendency that the states are abandoning the idea of absolutely free higher education, for example, from 2002 Austria instituted common tuition fees in cases where it takes a student more than two semesters longer than the standard amount of time to complete the course - the unified fee for all students from Austria and other EU countries in such a case is about 363 Euros for a semester; a standard fee for all students from third countries in all cases is about 727 Euros per semester (Kasparovsky, Wadsack, 2003).

The question regarding the payment for studies by students themselves is discussed in many countries. The decrease in economic abilities makes the tuition paid by the student a precondition for the survival of higher education. Tuition becomes a substantial source of financing. The discussion focuses on the question whether higher education is a private or a public investment. If we consider that the higher education is a private investment, then the primary beneficiary is the studying person, therefore he/she must contribute financially to the studies (Woodhall, 2007). In this sense, if the student does not pay, all tax payers pay for a private investment, even though only a small portion of them use this service. But if we consider higher education more public than private investment, considering it as a priority and as a value in a state, then it is proper for the whole society to contribute to the implementation of such an important activity.

At present, the main source of financing is still governmental funding. The advanced states allocate between 1 and 3 percent of GDP to higher education, this tendency prevails almost in the whole Europe. The states, where the part of GDP allocated to the higher education is higher than the average, have either very high quality elite higher education, financed by the state, due to high taxes (Switzerland) or they do not finance the other fields of education sufficiently or misuse the funds allocated (Constructing Knowledge Societies, 2002). In EU countries, the direct appropriations from the budget to higher education comprise between 60 and 90 percent of the funds received by the institutions of higher education. Only in the United Kingdom the private sector funds reach 25 percent of the whole financing of higher education, this index does not reach 20 percent in other countries (Canning et al., 2007). It is worthwhile to mention, that 
worldwide the states, which are presumed as being leaders in science and technology, have a model with a huge private funding impact on tertiary education, for example, in South Korea private funding constitutes 67.5 percent of the whole financing of higher education, in Japan this number is 65.8 percent (OECD, 2010).

Thus it can be seen again that due to the globalization and accessibility of higher education the financing of higher education is and may become an unbearable burden to states' tax systems, and the likely tendency is the establishment of student tuition and other private means of financing. But in the meanwhile, the state financing model should be effective, of quality and be sufficient. The models currently available and distinguished by the authors are institutional financing by "block financing" (called "financing according to the formula"), programme financing and financing of service recipient (CEGES, 2007; Stanfield, 2002; Estremann, Nokkala, 2009; Edirisooriya, 2003).

\section{State Financing Methods of Higher Education}

Institutional financing of higher education is the system of financing where the financing is given to the institution providing the services of higher education, considering the costs of studies and scientific research. This method had prevailed for a long time and still is applicable in many states of the world. The theory suggests that the state may have the biggest influence on the quality of higher education and to the process of studies if it uses this financing method. The state may also implement the state priorities for higher education by the financing means. Sometimes this method of state financing is called the method of the discretionary budget, as the state has the right of discretion to determine the amount allocated to a particular institution of higher education (Orr, 2005).

In most cases, the basis of the model of institutional state financing is the funds allocated to a particular institution based on a formula - it is called formulabased funding. The institution receives a pre-determined amount of funds according to its budget that had been approved. Usually, the funds received from the state budget are allocated to the budget of a higher education institution very particularly, by indicating a concrete aim for the use of a particular sum of money (for infrastructure, for wages, for the acquisition of equipment etc.). The rules on the calculation of the sum to be designated to a particular institution of higher education are very different, various criteria may be applied. Some states distinguish the funds for studies and funds for scientific research, other states do not finance these fields separately, the part allocated to scientific research is not designated. One of the criteria which is used in most of the states using this model of institutional financing is the number of students admitted to the institution of higher education. This criterion is supplemented with other criteria which are 
various and may be chosen by a particular state - for example, the number of credits obtained by students in a school year, the ratio between lecturers and students, the structure of wages of lecturers, learning outcomes, the number of high quality research papers, the number of the dissertations defended and other criteria. Scientific research as some study programmes might be financed separately, based on competitions won by a particular institution, or based on separate contracts with state institutions. Lithuania applied this state financing method from the restoration of independence in 1990 till the reform of higher education in 2009 (Dèl Lietuvos Respublikos valstybès biudžeto lèšų poreikio..., 2006).

The method of formula - based funding is used in Finland (Davies, et al., 2009; Bologna Process in Finland, 2005; Universities 2005, 2006; Liuhanen, 2005). In Finland, all the universities (about 20 institutions of higher education and 10 specialized institutions - polytechnic schools) are state universities, but they retain relatively broad autonomy regarding the institution, study matters, science and internal administration. ${ }^{1}$ Investments by the public sector in studies and science comprise 2.2 percent of Finland's GDP, that is one of the highest indicators in the EU. The state funds comprise the largest share of the financing of higher education - almost 90 percent; this is also one of the highest indicators in the EU member states. Universities are financed according to the formula (formula - based funding), a particular method of calculation of funds, which is largely based on performance (performance - based funding). The amount of funds allocated is determined according to the indicated criteria and is set out in a contract between the university and ministry. The contract usually states the directions of the development of the university and its main aims. The tuitions are not applied to Finnish citizens, due to high taxes that have to cover all the costs of public services, including higher education. The institutions of higher education receive additional financing by providing services (for example, continuous learning and qualification courses), also through external sources of financing for research and project activity. The financing of science and research in Finland is one of the highest in the world, comprising about 4 percent of Finnish GDP. In 2014 the financing system of the universities of applied sciences has been renewed to be more performance-based. The new funding model emphasizes quality, impact and efficiency. The institution-specific funding will be primarily

\footnotetext{
${ }^{1}$ The Universities Act was reformed in 2009. The law further extended the autonomy of universities by giving them an independent legal status, either as public corporations or as foundations under private law. At the same time, the universities' management and decision-making system was reformed. The financing system of the universities of applied sciences has been renewed to be more performance-based. The new funding model emphasises quality, impact and efficiency. The institution-specific funding will be primarily determined on the basis of degrees awarded, the quality and efficiency of study processes and R\&D. Universities Act, 2011.
} 
determined on the basis of degrees awarded, the quality and efficiency of study processes and research and development (Eurydice, 2017).

Programme-based financing is a different method of allocation of state funds to institutions of higher education. This method allows the state to designate funds to particular study programmes, indicating the aims, which should be attained by the institution executing the study programme and students after their studies. The institutions may compete regarding the execution of the programme. Some authors call this method performance - based funding, where the institution of higher education is financed according to the methodology adopted by the state in advance (usually the considered criteria are the number of students who were admitted and who finished the studies, scientific research performed by the university and the results of this activity - research papers) (Orr, 2005; Becher, Kogan, 1992). This method is more convenient for the market financing model in the system of higher education, but it also has the same disadvantages that are discussed regarding the institutional state financing method. Even though it is stated that programme-based financing helps to ensure the quality of studies, but the fact is that usually the same programme is financed not for one year, but at least for four years (until students finish their studies) therefore the final result is seen only after one cycle of financing. Furthermore, programme-based funding also raises questions regarding quality control, because the state being the client of services and seeking to ensure their quality usually created state supervision mechanisms and they might condition the implementation of extensive bureaucratic processes. However, it should be noted that this method allows to effectively coordinate the quality of the study programmes in the process of their execution. This is also an effective method to allocate funds for scientific research.

It can be noted that in the case of institutional-based and programme-based state funding, there two main means of the distribution of the state budget funds to the institutions of higher education. Block - grant funding is the funding where the state budget funds are allocated to cover certain expenses, like study costs, everyday activity costs etc., and the universities are responsible for the distribution of those funds according to their needs inside the institution. Line item budget funding means that universities are financed from the budget when the funds are assigned to particular expenses or activities and the universities may not distribute those funds independently. The line - item financing is usually set by the state parliament or the particular ministry, this method exists in Cyprus, Greece and Turkey, and until 2009 it was applied as well in Lithuania. The block grant funding is applied in twenty-two European states, but not in all of them the universities have full discretion to distribute the funds received. For example, in Sweden or Slovenia, the funds are allocated in blocks (for example, for research, wages, and infrastructure) and the universities cannot move the funds from one 
block to another. An independent decision may be taken only regarding the redistribution of the funds inside the blocks (Estermann et al., 2011).

The system of block - grant funding is applied in the United Kingdom (the information provided according to Estremann, Nokkala, 2009; Relchert, 2009; Financially Sustainable Universities, 2008; Dill, Teixeira, 2000; Douglass, 2004). The state funds are allocated after having established the need of a particular institution of higher education for the financial year according to the methodology adopted by state institutions. The funds are allocated separately for studies and for research. The institutions of higher education distribute the funds freely for their needs, and are accountable to the self-governing body - to the university council. Until 1998 studies in the United Kingdom were financed by the state, but from 2006 the student tuition was established. The minimum and maximum amount is determined by the state, but the higher education institutions may establish their tuition within those limits. Therefore presently a considerable part of the income of the institutions of higher education consists of the student tuition which is paid by all students (from 2009 it is up to 3300 pounds a year), except for the students who receive state or university scholarships. The income from tuitions is paid into the overall budget of the institution, but they have to collect those sums themselves. The universities can admit students who pay the full cost of their studies as well.

However, the tendencies that are faced by the institutions of higher education everywhere in the world did not bypass also the United Kingdom - instable number of students (there was considerable growth in past decade, and now a decrease in this number is seen in the light of the present political situation), the internationality of higher education, state financial hardships determined the fact that presently there are discussions in the United Kingdom about the reform of financing of studies, which would increase the tuition for all students. There are discussions as well regarding the revision of the system of block - grant funding and regarding the possibility to establish the financing principle of service recipient (student's purse).

The financing method of service recipient is oriented towards the direct financing of the service recipients - students when it is upon the student to determine which institution of higher education will receive the funds allocated to his/her higher education. It is maintained that this method of financing encourages the competition of the institutions of higher education and created premises for effective and quality activity. By this, the universities become fully independent from state policy or short - term goals because the last word belongs to the service recipient. In most cases, the method is implemented through the mechanism of "purse", where the student receives certain state funds to finance studies and their costs and "brings" them to the higher education institution that he/she chooses. The cost of studies is composed of all costs for the activity of the 
institution of higher education, which should be covered by the student's purse. Of course, only the state-funded student tuitions are not sufficient, therefore this financing method should be combined with other alternatives of financing. It can be concluded that when the abovementioned financing model is in place, this model comes the nearest to the market model in the financing of the system of higher education.

The mechanisms of the application of this method can be several. The price of studies for a certain programme may be determined centrally (by the state), or decentrally (by the institution). The accessibility of studies may be ensured by state funds to the students whose study results are the best, on the entry to the institution of higher education - to the graduates who had the best results-, by using the student purse financial instrument. The remaining costs (if the study programme costs more than the size of student purse or if the student is not advanced in study results) could be covered by study tuition. The size of student purse may vary every year depending on the structural changes (for example, the increase in wages) or may be stable during the whole period of studies. It is discussed what costs may be covered by the student's purse - should it cover only direct costs or could it cover also indirect expenses of the institution of higher education. Direct costs are usually considered to include the wages of lecturers and other personnel, expenses for goods and services directly related to studies, the expenses for organizing cultural, sport, social activities of students. The financing method of service recipient may be used with other methods of state financing for higher education. For example, in Lithuania the funds of science and study institutions are composed of state basic financing studies, intended for scientific research, administration and property, also state budget funds for studies (allocated on the basis of student's purse), funds from state investment programmes and projects, income from programme - competition scientific research (Law on science and studies, Article 74).

The alternative financing instrument used by the state may be the provision of loans, where the state provides favourable loans to cover the study tuitions, and if the state is not capable enough to ensure state loans, it can guarantee the return of loans given by private institutions or can compensate for the interest rate. The students start to repay the loans usually after studies or when the income of the former student reaches a particular level indicated by the state. In this case, the state has to determine by legal and administrative measures the system of remedies aiming at the elimination of problematic situations (state guarantees in case of insolvency of the borrower; the review of conditions of the repayment of the loan if the person emigrates; the conditions for loans which cover costs not directly related to studies).

Another measure that is less popular is the provision of support to the families which include persons studying. This mechanism is applied, for example, 
in Belgium, Austria, Portugal. The state support usually is related to tax exemptions, but it should be noted that is it used together with other instruments of financing of higher education.

\section{Conclusions}

A particular model of financing of higher education and a state financing method depends on political interests and the state's strategy, knowledge about economic theories and the influence of public opinion. But in any case the chosen directions of financing have to conform to world trends, which have influence on the whole system of higher education: the diversification of financial sources, attracting private and business funds; the creation of a system for the effective use of state budget appropriations for higher education; the magnification of financial autonomy of higher education; the improvement of the system of crediting of studies. The increase of financing from the state budget to universities cannot alone solve the problems of financing as the possibilities of the state budget are limited, therefore it is very important that the universities look for financing sources by themselves as well. As international experience confirms, the state should not rely on a single source of funding in the higher education system. Applying a particular state financing method positive as well as negative outcomes may be found. On the one hand, funding formulas may be seen as an acceptable instruments for allocation core resources but they are not always able to ensure the achieved quality or to ensure greater equity in higher education. On the other hand, indirect financing mechanisms (such as service recipient approach), financing the recurrent expenses of higher education institutions indirectly through a ,purse“ provided to the students, often are a better choice in promoting access and equity, but they are not always reliable reaching long-term goals of higher education.

\section{References}

Becher, T., Kogan, M. (1992). Process and Structure in Higher Education. London: Routledge. Canning, M., Godfrey, M., Holzer-Zelazewska, D. (2007) Higher Education Financing in the New EU Member States. Leveling the Playing Field. World Bank Working Paper No. 112. Washington: World Bank. Retrieved from http://www-wds.worldbank.org/external/ default $/$ main? $\mathrm{menuPK}=64187510$ \&pagePK $=64193027 \& \mathrm{piPK}=64187937 \&$ theSitePK=5 $23679 \&$ menuPK $=64154159$ \&searchMenuPK $=64258545 \&$ theSitePK $=523679$ \&entityID $=000020953$ 20070822083352\&searchMenuPK $=64258545 \&$ theSitePK $=523679$.

CEGES. (2007). Rates of Return and Funding Models in Europe. Final report to the Directorate - General for Education and Culture of the European Commission. Valencia: Centre for the Study of Higher Education management. 
Commission of the European Communities. (2007). Rates of Return and Funding Models in Europe. Final report to the Directorate - General for Education and Culture of the European Commission. Retrieved from www.ec.europa.eu.

Constructing Knowledge Societies: New Challenges for Tertiary Education. (2002). Washington: The World Bank, 2002. Retrieved from http://siteresources.worldbank.org/ TERTIARYEDUCATION/Resources/Documents/Constructing-KnowledgeSocieties/ConstructingKnowledgeSocieties.pdf.

Davies, J., Weko, T., Kim, L., Thulstrup, E. (2009). Finland. OECD Reviews of Tertiary Education. Retrieved from http://www.oecd.org/edu/skills-beyond-school/ 37474463.pdf.

Davies, J., Weko, T., Kim, L., Thulstrup, E. (2009). OECD Reviews of Tertiary Education. Finland. OECD.

Department for Education and Skills. (2003) The Future of Higher Education. Retrieved from http://webarchive.nationalarchives.gov.uk/20100210151716/dcsf.gov.uk/hegateway/upl oads/white\%20pape.pdf.

Dill, D. Teixeira, P. (2000). Program diversity in higher education: an economic perspective, Higher Education Policy, 13, 99-118. http://dx.doi.org/10.1016/S0952-8733(99)00026-4

Douglass, J.A. (2005). The dynamics of massification and differentiation: A comparative look at higher education systems in the United Kingdom and California, Higher Education Management and Policy. 16(3), 9-35. http://dx.doi.org/10.1787/hemp-v16-art21-en.

Edirisooriya, G. (2003). State Funding of Higher Education: A New Formula. Higher Education Policy, 16, 121-133. doi:10.1057/palgrave.hep.8300006.

Estermann, T., Nokkala, T., Steinel M. (2011). University Autonomy in Europe II. The Scorecard. European University Association.

Estremann, T., Nokkala, T. (2009). University Autonomy in Europe I. Brussels: European University Association.

Eurostat. (2012). Public expenditure on tertiary education as a share of GDP. Retrieved from http://ec.europa.eu/eurostat/statistics-explained/index.php/File:Public_expenditure_on_ tertiary_education_as_a_share_of_GDP,_2012_(\%C2\%B9)_(\%25)_ET15.png.

Eurostat. (2016) Educational Expenditure Statistics. Retrieved from http://ec.europa.eu/ eurostat/statistics-explained/index.php/Educational_expenditure_statistics\#Overall_ educational_expenditure.

Eurydyce (2017). Finland. Higher Education. 2017. Retrieved from https://webgate.ec. europa.eu/fpfis/mwikis/eurydice/index.php/Finland:Higher_Education.

Financially Sustainable Universities: Towards full costing in European universities. (2008). Brussels: European University Association.

Funding Higher Education: a View Across Europe. (2010), Brussels: European Centre for Strategic Management of Universities, 2010.

Lietuvos Respublikos Seimas (2016). Mokslo ir studiju istatymas (2016 m. birželio 29 d., Nr. XII-2534). Retrieved from TAR.lt.

Lietuvos Respublikos Vyriausybė (2006). Dél Lietuvos Respublikos valstybès biudžeto lëšu poreikio nustatymo ir ju skyrimo mokslo ir studiju institucijoms metodikos patvirtinimo. (Valstybès žinios, 2006, Nr. 108-4114). Retrieved from TAR.1t.

Liuhanen, A.M. (2005). University evaluations and different evaluation approaches: A Finnish perspective. Tertiary Education and Management, 11, 259-268.

Kasparovsky, H., Wadsack, I. Higher Education in Austria. (2004) Vienna: The Federal Ministry of Education, Science and Culture. 
Birutè Pranevičienè, Aurelija Pūraitè, Violeta Vasiliauskienè, Žaneta Simanavičienè. Comparative Analysis of Financing Models of Higher Education

National Center for Education Statistics (2012) Education Expenditures by Country. Retrieved from https://nces.ed.gov/programs/coe/pdf/coe_cmd.pdf

OECD (2017), Spending on tertiary education (indicator). doi: 10.1787/a3523185-en Retrieved from https://data.oecd.org/eduresource/spending-on-tertiary-education.htm

Orr, D. (2005) Can Performance - Based Funding and Quality Assurance Solve State vs Market Conundrum? Higher Education Policy, 18, 31-50. doi:10.1057/palgrave.hep.8300071.

Pranevičienè, B., Pūraitè, A. (2010). The Financing Methods of Higher Education System. Jurisprudence, 4(122), 335-356.

Relchert, S. (2009). Institutional Diversity in European Higher Education. Tensions and challenges for policy makers and institution leaders. Brussels: European University Association, 21-44.

Salmi, J., Hauptman, A.M. (2006) Innovations in Tertiary Education Financing: A Comparative Evaluation of Allocation Mechanisms. Education. Working Paper Series.

No. 4. Washington: World Bank. Retrieved from http://siteresources.-worldbank.org/ EDUCATION/Resources/278200-1099079877269/5476641099079956815/-Innovatio ns_TertiaryEd_Financing.pdf

Schleicher, A. (2006) Europe's university challenge. OECD Observer, 254. Retrieved from http://www.oecdobserver.org/news/fullstory.php/aid/1889/.

Stanfield, J. E. G., (2002). Higher Education New Ideas From Around The World. Konferencijos "Lietuvos aukštasis mokslas: diagnozès ir prognozès” medžiaga. Vilnius: Lietuvos laisvosios rinkos institutas, Žinių ekonomikos forumas, 50-66.

The Bologna Process in Finland. (2005) Turku. Retrieved from http://www.minedu.fi/ $\mathrm{OPM} / \mathrm{Julkaisut} /$ ?lang=en.

Universities 2005. Annual Report. (2006). Helsinki: Ministry of Education, 2006. Retrieved from http://www.minedu.fi/export/sites/default/OPM/Julkaisut/2006/liitteet/opm31.pdf? lang=en.

Universities Act 558/2009 (As amended up to 315 /2011). (2011). Unofficial translation. Retrieved from http://www.finlex.fi/en/laki/kaannokset/2009/en20090558.pdf

Woodhall, M. (2007). Funding Higher Education: The Contribution of Economic Thinking to Debate and Policy Development. Education. Working Paper Series. No. 8. Washington: World Bank. Retrieved from http://siteresources.worldbank.org/EDUCATION/ Resources/278200-1099079877269/547664-1099079956815/Funding_HigherEd_wps 8.pdf. 